\title{
Elucidating Acidic Electro-Oxidation Pathways of Furfural on Platinum
}

Alex M. Román ${ }^{1,2}$, Joseph C. Hasse ${ }^{1,2}$, J. Will Medlin ${ }^{1,2}$, and Adam Holewinski ${ }^{1,2 *}$

${ }^{1}$ Department of Chemical and Biological Engineering and ${ }^{2}$ Renewable and Sustainable Energy Institute, University of Colorado, Boulder, Colorado 80309, United States

Supplemental Information Contents:

1. Differential packed bed electrochemical flow reactor diagrams

2. Rotating disc electrode (RDE) studies at variable furfural concentration

3. Calculation of partial current, selectivity, faradaic efficiency, and e-/ $\mathrm{CO}_{2}$

4. Faradaic efficiencies for furfural and furoic acid oxidation

5. Product identification details

6. SEM Image of the Pt film used in ATR-SEIRAS

7. ATR-IR Standards

8. Deconvolutions of furfural voltammetric stripping ion currents

9. Voltammetric stripping of furfural oxidation products vs. adsorption time

\section{Differential packed bed electrochemical flow reactor diagrams}
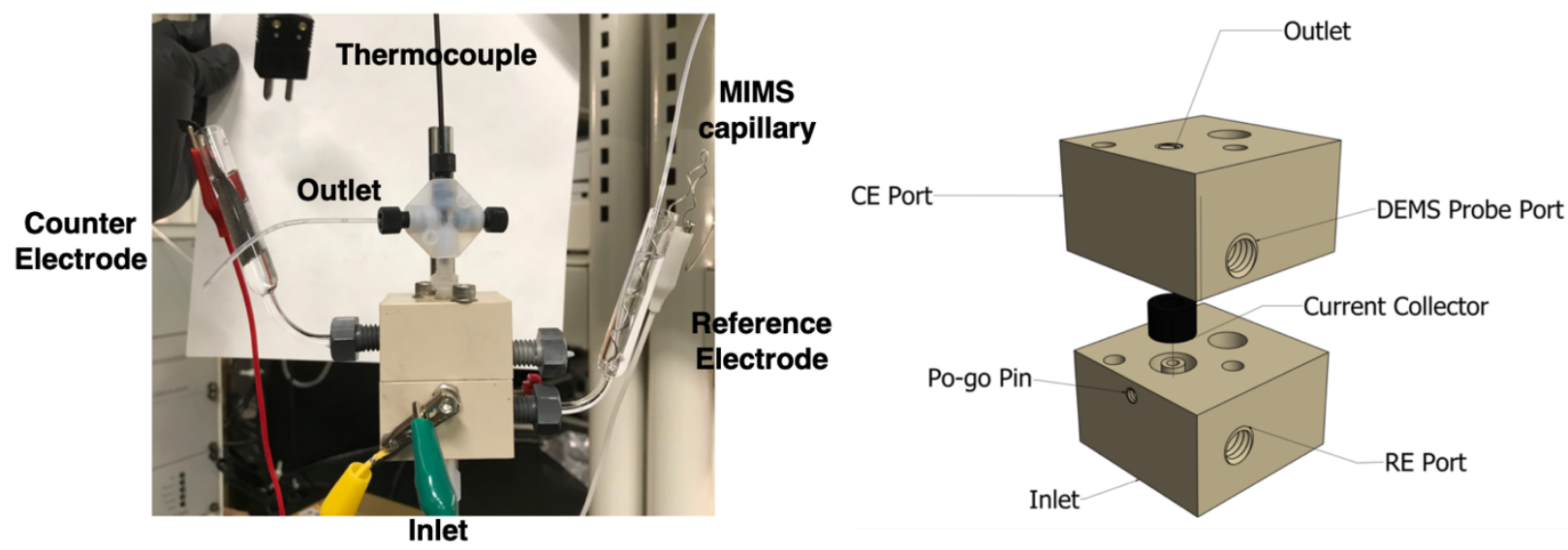

Figure S1: Labelled flow cell during operation (left) and exploded CAD drawing showing internal configuration (right) 


\section{Rotating disc electrode (RDE) studies at variable furfural concentration}

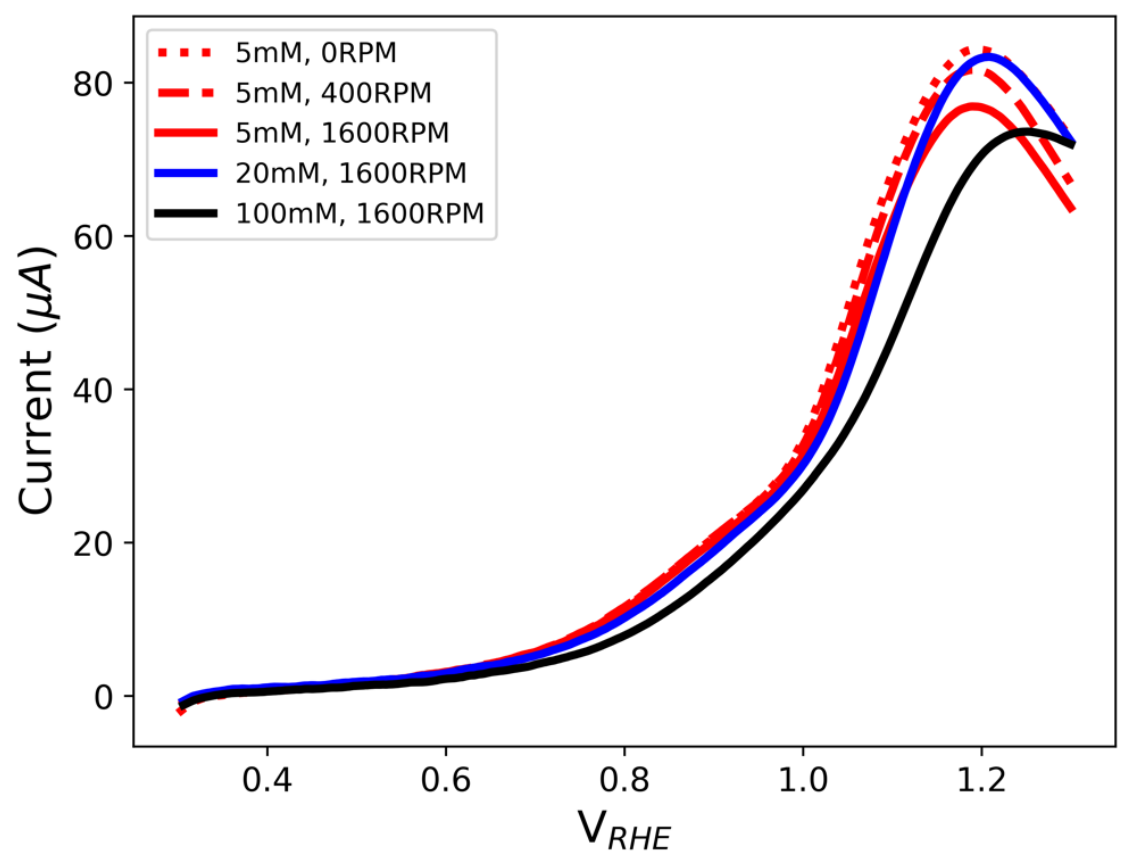

Figure S2: Rotating disc electrode (RDE) linear sweep voltammograms for $\mathrm{Pt} / \mathrm{C}$ at select conditions in $5-100 \mathrm{mM}$ furfural $+0.25 \mathrm{M} \mathrm{HClO}_{4}$. Scan rate $=10 \mathrm{mV} / \mathrm{s}$. A very low reaction order (near zero) is seen with respect to furfural, with small inhibition effect moving to $100 \mathrm{mM}$. Rotation suppresses currents at higher potential, indicating that some oxidizable products can readsorb if they are not quickly removed. 


\section{Calculation of partial current, selectivity, faradaic efficiency and $\mathrm{e} / \mathrm{CO}_{2}$}

Steady State Electro-Oxidation Experiments

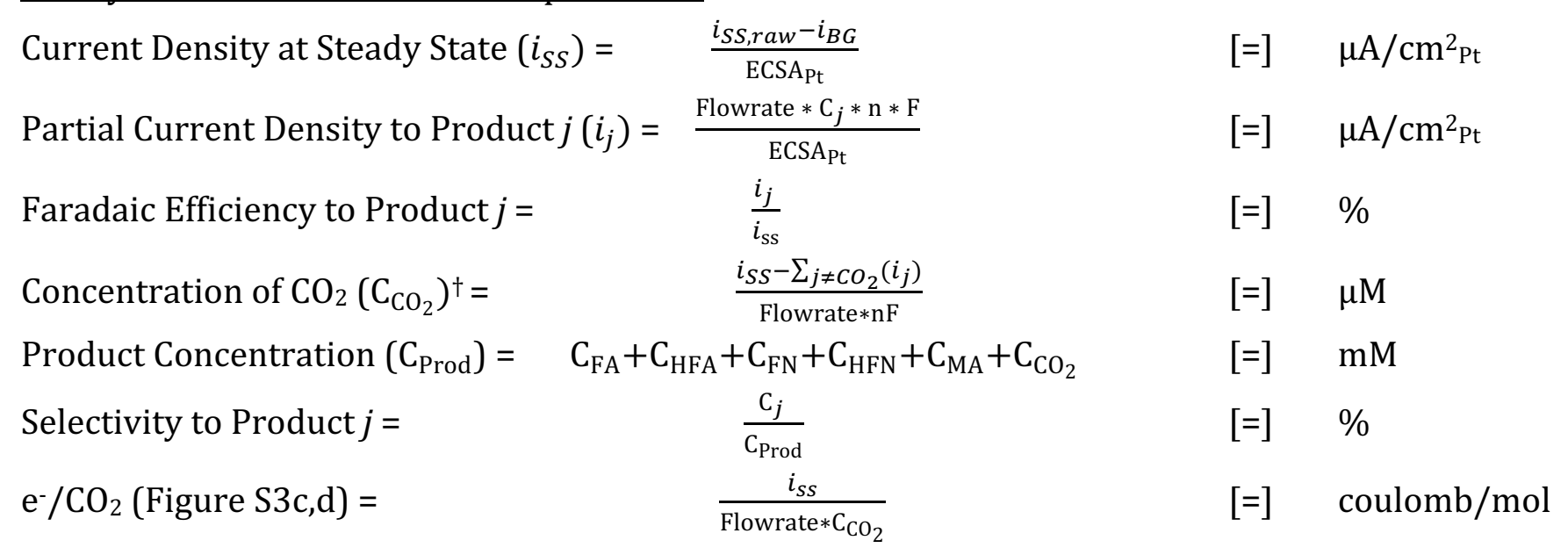

where:

$\begin{array}{lll}i_{S S} & = & \text { raw current at steady state } \\ i_{B G} & = & \text { background current (recorded post reaction, no organic present) } \\ \text { ECSA }_{P t} & = & \text { electrochemically active surface area of Pt determined via HUPD } \\ \mathrm{n} & = & \text { number of electrons to a given product } \\ \mathrm{F} & = & \text { Faraday's constant }\end{array}$

† Due to its low concentration $(<50 \mu \mathrm{M})$, overlapping mass fragment from furfural $(\mathrm{m} / \mathrm{z}=44)$, and the lack of evidence of alternative products (using HPLC-MS/HPLC-UV/NMR, further details shown below), the concentration of $\mathrm{CO}_{2}$ was quantified indirectly via unaccounted current.

\section{$\mathrm{CO}_{2}$-OLEMS Calibration to find $\mathrm{e}^{-} / \mathrm{CO}_{2}$ and $\mathrm{CO}_{2} / \mathrm{Pt}$ atom (Figure 6 )}

A calibration constant was calculated via a $\mathrm{CO}$ stripping experiment paired with $\mathrm{CO}_{2}$-OLEMS $(m / z=44)$ through the following expression:

$$
\mathrm{K}_{44}^{*}=\frac{2 \mathrm{Q}_{\mathrm{i}, \mathrm{CO}}}{\mathrm{Q}_{\mathrm{f}, \mathrm{CO}}}[=] \text { ion counts } / \mathrm{CO}_{2}
$$

$\mathrm{Q}_{\mathrm{i}}$ and $\mathrm{Q}_{\mathrm{f}}$ are the integral faradaic and $m / z=44$ ion charges, respectively, recorded during the oxidation of a monolayer of adsorbed $\mathrm{CO}$ to $\mathrm{CO}_{2}$. The factor 2 is associated with the number of electrons required to produce $\mathrm{CO}_{2}$ during the stripping experiment. This constant can then be used to determine the relative number of electrons per $\mathrm{CO}_{2}$ formed in other stripping experiments:

$$
\mathrm{e}^{-} / \mathrm{CO}_{2} \text { for Species } j=\mathrm{K}_{44}^{*} * \frac{\mathrm{Q}_{\mathrm{f}, \mathrm{j}}}{\mathrm{Q}_{\mathrm{i}, \mathrm{j}}}
$$

In addition, the $\mathrm{CO}_{2}$ yield in stripping can be normalized to the approximate number of Pt sites by referencing a theoretical CO saturation coverage of 0.68 monolayert+ :

$$
\mathrm{CO}_{2} / \text { Pt Atom for Species } j=\frac{\mathrm{Q}_{\mathrm{i}, \mathrm{j}}}{\mathrm{Q}_{\mathrm{i}, \mathrm{CO}}} * 0.68
$$

†† Vidaković, T., Christov, M., and Sundmacher, K. The use of CO stripping for in situ fuel cell catalyst characterization. Electrochim. Acta 2007 52, 5606-5613 


\section{Faradaic efficiencies for furfural and furoic acid oxidation}
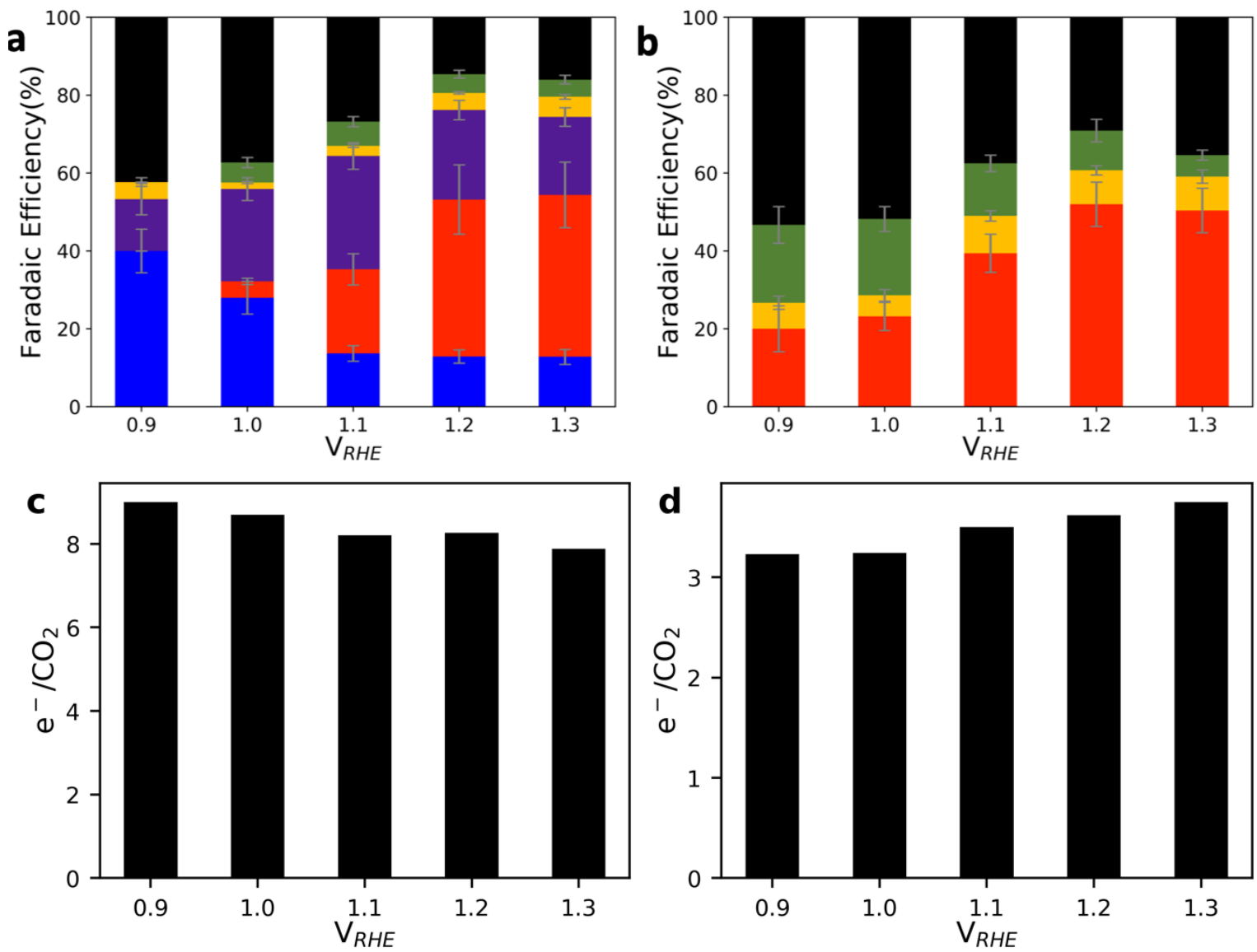

Figure S3: Faradaic efficiencies towards major products and electrons per $\mathrm{CO}_{2}$ for the electrooxidation of (a,c) $100 \mathrm{mM}$ furfural and (b,d) $100 \mathrm{mM}$ furoic acid on Pt/C in $0.25 \mathrm{M} \mathrm{HClO}_{4}$ at steady state. Furoic acid (blue), 5-hydroxy-2(5H)-furanone (red), 5-hydroxyfuroic acid (purple), maleic acid (yellow), 2(3H)-furanone (green), and terminal $\mathrm{CO}_{2}$ (black). 


\section{Product identification details}

While commercially-available products were directly verified with purchased standards, assignment of 5-hydroxyfuroic acid (HFA) was based on multiple datasets-most crucially LC-MS and ${ }^{1} \mathrm{H}-{ }^{-1} \mathrm{H}$ correlation spectroscopy (COSY) using NMR. Key analyses are presented below.

Table S1: Summary of analytical information used to elucidate the structure of major unknown compound in furfural electro-oxidation. Expanded information available below.

\begin{tabular}{|c|c|c|}
\hline Technique & Major Findings & Conclusions \\
\hline HPLC-UV & $\begin{array}{l}\text { Elutes immediately after maleic acid, yet before } \alpha \text { - } \\
\text { ketoglutaric acid (more LC detail in Table S2); much } \\
\text { shorter retention than ring compounds } \\
\lambda_{\max }=200 \mathrm{~nm}\end{array}$ & $\begin{array}{l}\text { - Linear, conjugated compound } \\
\text { Taken together with NMR, the pH and } \\
\text { temperature in column may cause ring } \\
\text { opening }\end{array}$ \\
\hline $\begin{array}{l}\text { LC-MS } \\
\text { (ESI/APCI) }\end{array}$ & $\begin{array}{l}\text { - } \quad m / z=127 \text { and } 145 \text { (negative mode) } \\
\text { - } \quad \text { Not present in furoic acid oxidation experiments }\end{array}$ & $\begin{array}{l}\text { - Either } \mathrm{C}_{5} \mathrm{H}_{4} \mathrm{O}_{4} \text { with hydrate or } \mathrm{C}_{5} \mathrm{H}_{6} \mathrm{O}_{5} \text { with } \\
\mathrm{H}_{2} \mathrm{O} \text { loss during ionization } \\
\text { Negative ionization often indicates } \\
\text { carboxylic acid group }\end{array}$ \\
\hline $\begin{array}{c}\text { H-NMR } \\
(1 \mathrm{D} / \mathrm{COSY})\end{array}$ & - $\quad$ Major peaks correlated at 5.91, 6.15, and $6.22 \mathrm{ppm}$ & $\begin{array}{l}\text { Three alkenoic or tertiary C-H's on same } \\
\text { molecule }\end{array}$ \\
\hline
\end{tabular}<smiles>O=C(O)C1(O)C=CC(O)O1</smiles>

$$
\mathrm{MW}=146.1
$$
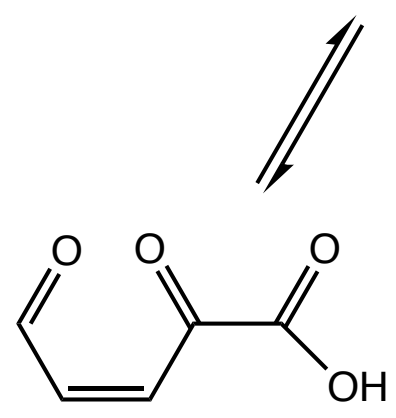

$$
\mathrm{MW}=128.1 \quad \mathrm{MW}=128.1
$$$$
1
$$

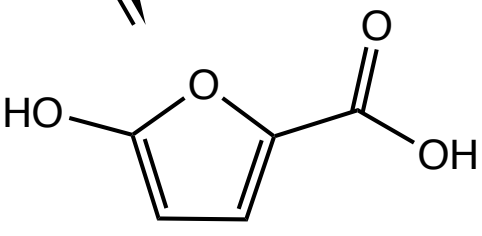

Scheme S1: Proposed equilibrium of 5-hydroxyfuroic acid in aqueous environment 


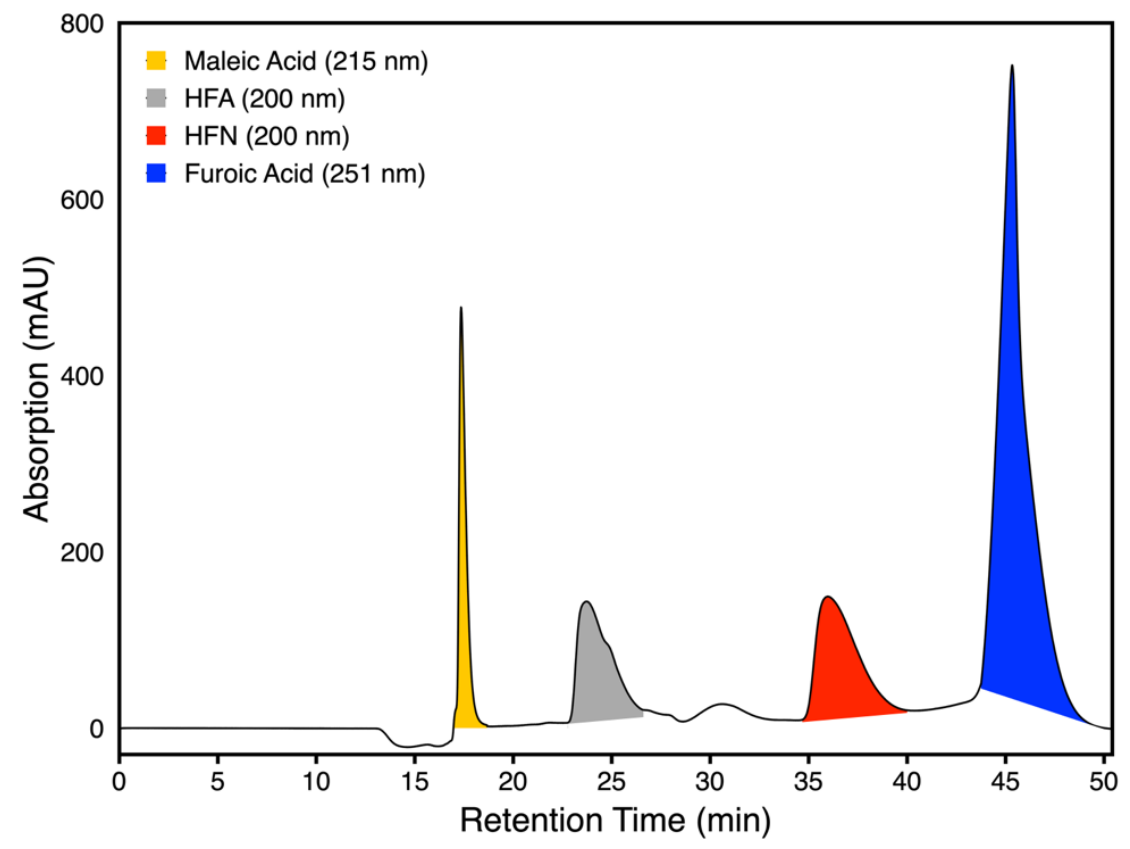

Figure S4: Typical UV chromatogram for a furfural electro-oxidation sample taken at $1.1 \mathrm{~V}_{\mathrm{RHE}}$

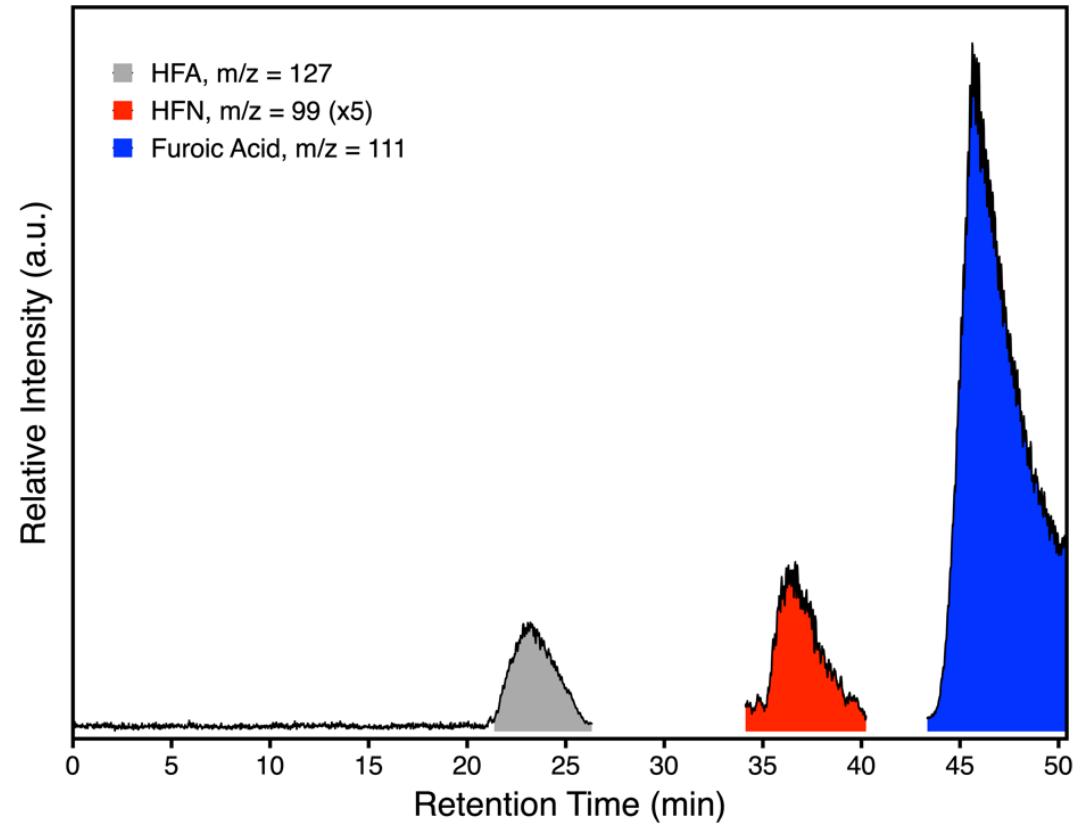

Figure S5: APCI (Negative Mode) chromatogram for a furfural electro-oxidation sample taken at 1.1 $V_{\text {RHE. }}$ First 20 minutes of run were diverted to waste to avoid electrolyte introduction into the ion source. 


\begin{tabular}{|c|c|c|c|}
\hline Standard & $\underline{\text { MW }}$ & $\frac{\text { Peak Elution Time }}{\text { (min) }}$ & Structure \\
\hline Maleic Acid & 116.1 & 17 & \\
\hline$\alpha$-Ketoglutaric Acid & 146.1 & 20.5 & \\
\hline L-Tartaric Acid & 150.1 & 22.2 & \\
\hline L/D-Malic Acid & 134.1 & 23.8 & \\
\hline Succinic Acid & 118.1 & 27.8 & \\
\hline Fumaric Acid & 116.1 & 28.4 & \\
\hline$\beta$-Formylpropionic Acid & 102.1 & 29.8 & \\
\hline 5-Hydroxy-furan-2(5H)-one & 100.1 & 31.8 & \\
\hline Tetronic Acid & 100.1 & 33.5 & \\
\hline Furoic Acid & 112.1 & 36 & \\
\hline $2(5 \mathrm{H})$-Furanone & 84.1 & 38 & \\
\hline 2-Furanol & 84.1 & 41 & \\
\hline Furan & 68.1 & 52.3 & \\
\hline Furfural & 96.1 & 57.8 & \\
\hline
\end{tabular}

Table S2: Elution times of various standards using HPLC method described in text: Sulfonated polystyrene column (Agilent Hi-Plex $\mathrm{H}$ ), $60^{\circ} \mathrm{C}$, isocratic $0.01 \%$ formic acid in water eluent. 
${ }^{1} H$-NMR Spectroscopy (1D and COSY)

Shown below are representative H-NMR spectra taken from a sample produced at $1.1 \mathrm{~V}_{\mathrm{RHE}}$ in the flow reactor.

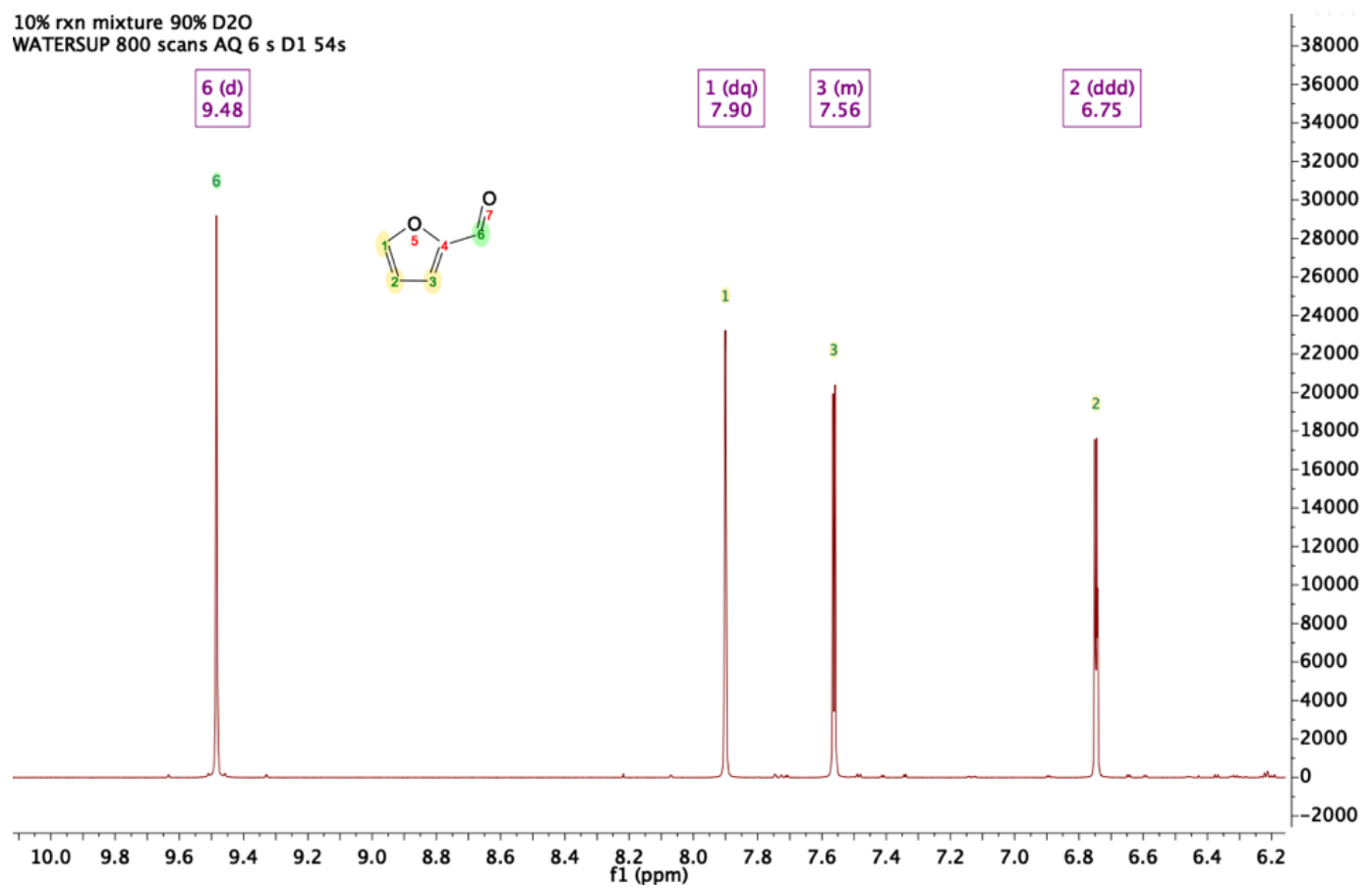

Figure S6: Example ${ }^{1} \mathrm{H}-\mathrm{NMR}$ spectra of furfural

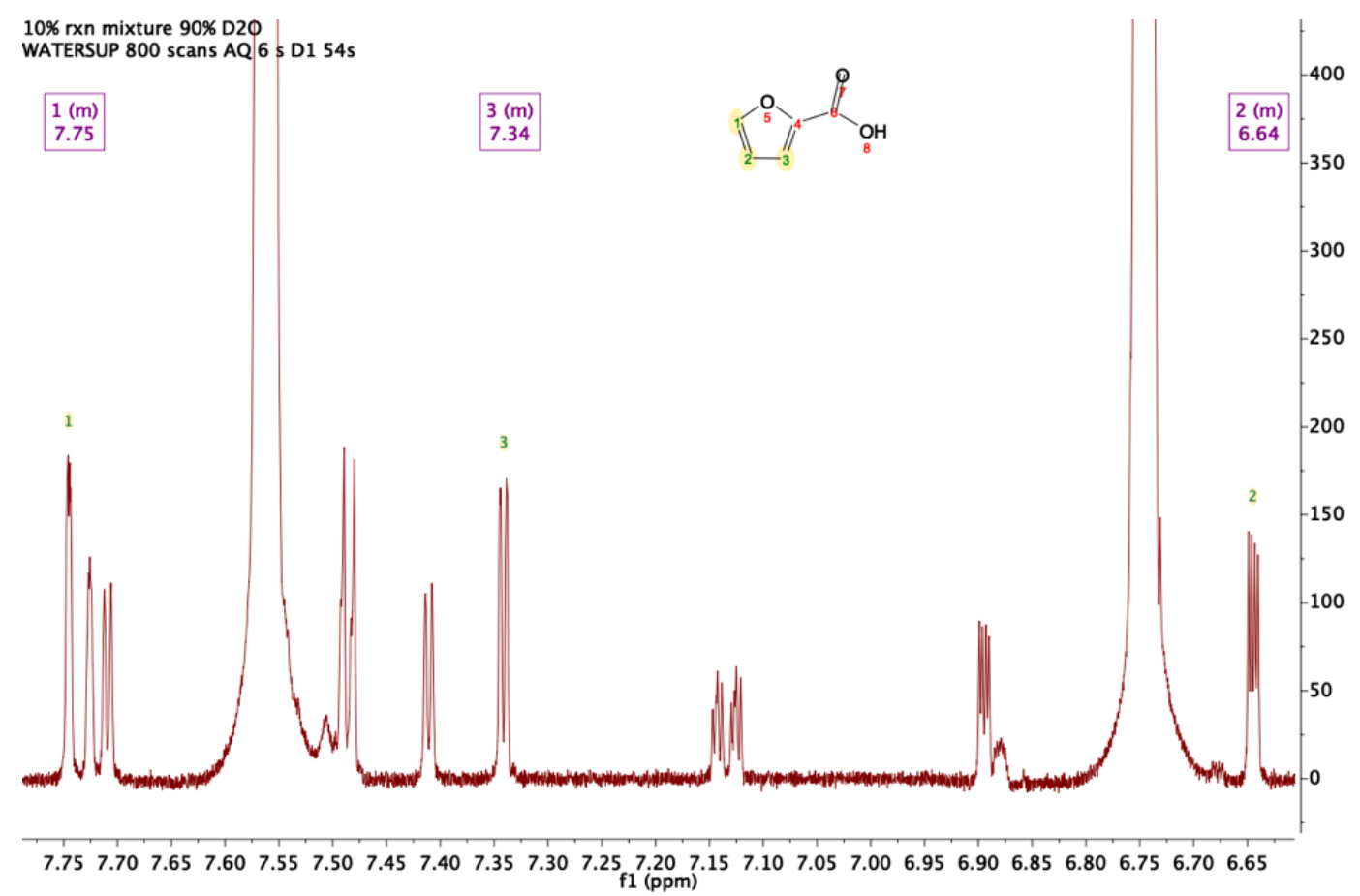

Figure S7: Example ${ }^{1} \mathrm{H}-\mathrm{NMR}$ spectra of furoic acid 


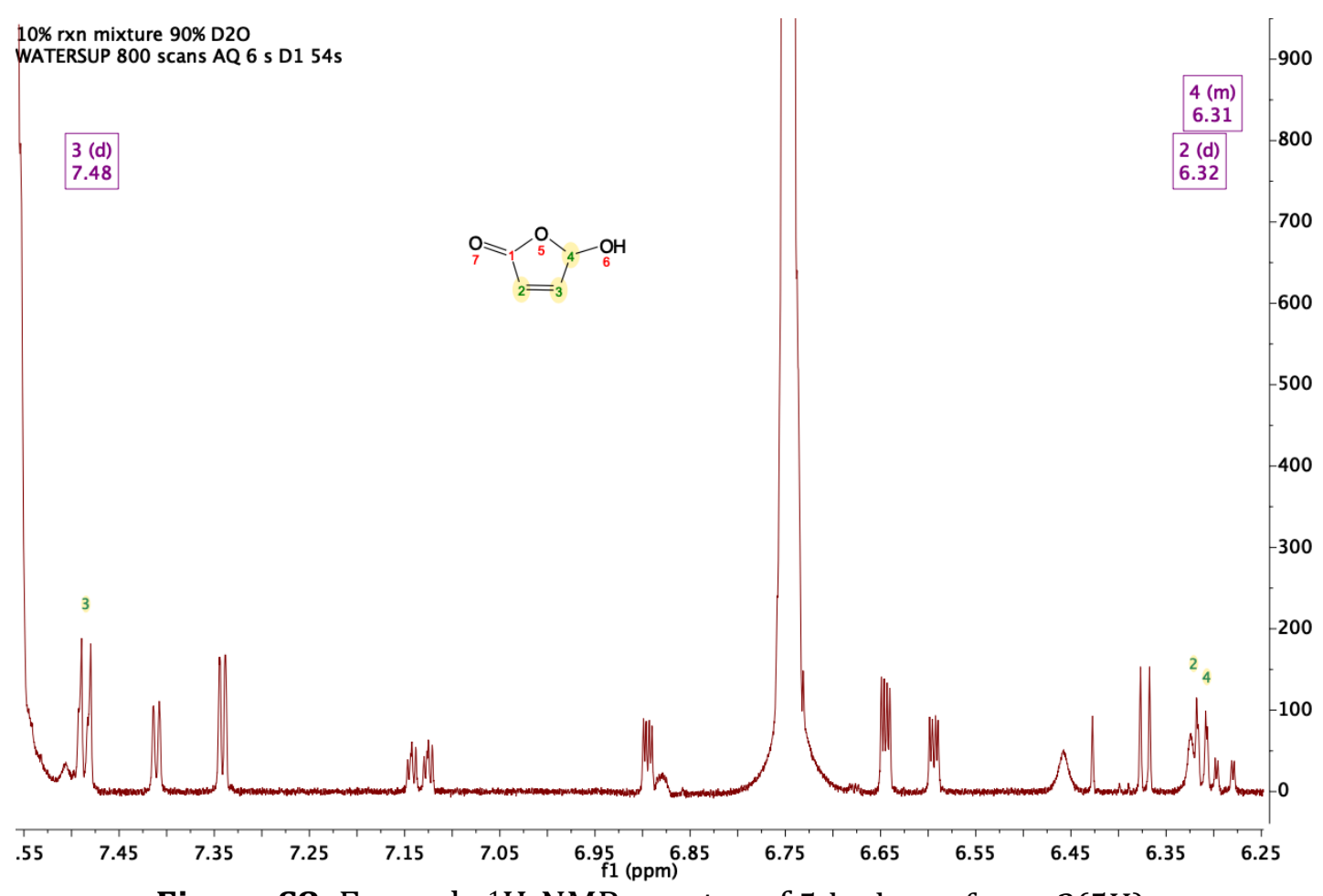

Figure S8: Example ${ }^{1} \mathrm{H}-\mathrm{NMR}$ spectra of 5-hydroxy-furan-2(5H)-one

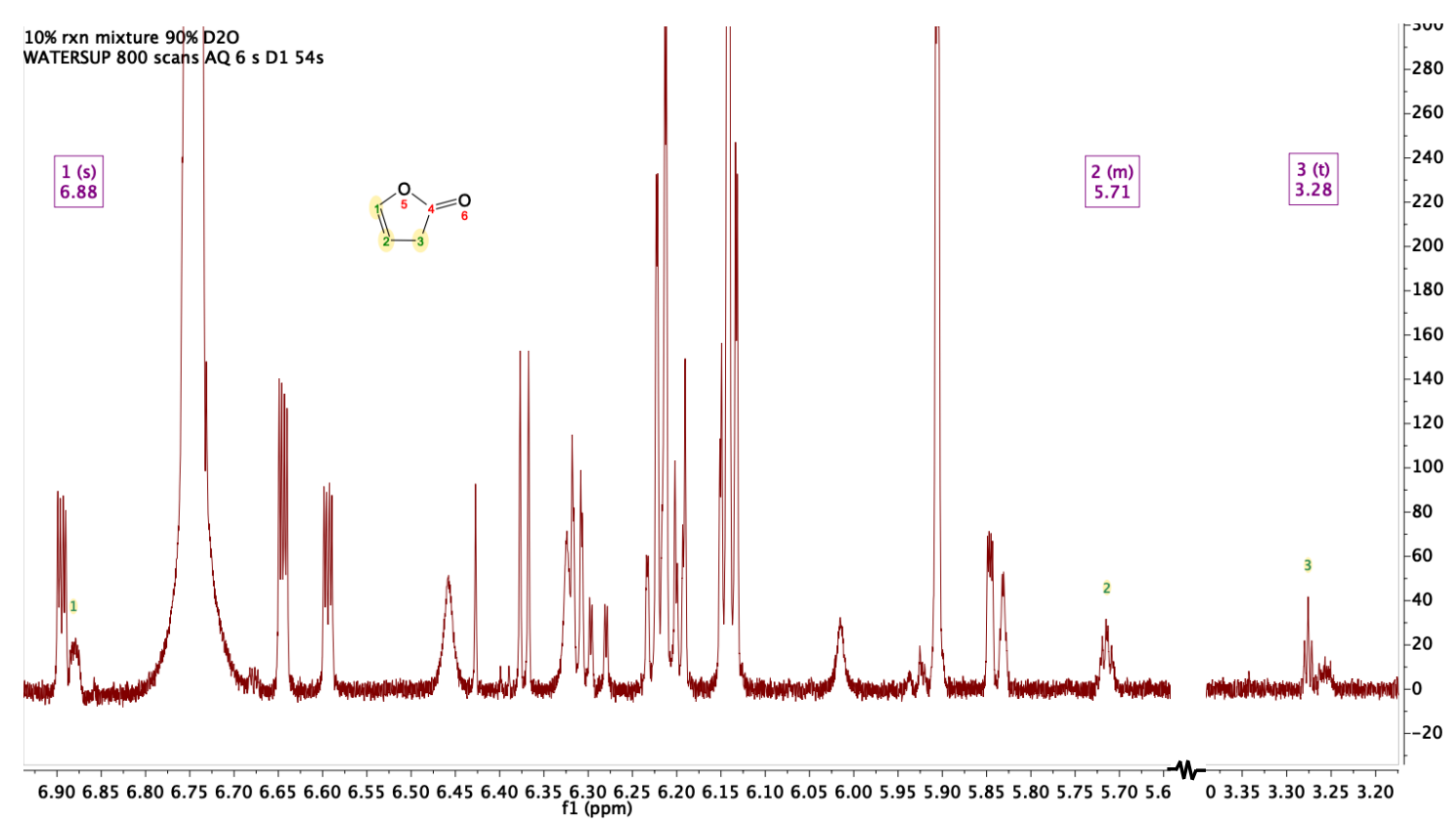

Figure S9: Example ${ }^{1} \mathrm{H}-\mathrm{NMR}$ spectra of $2(3 \mathrm{H})$-furanone 


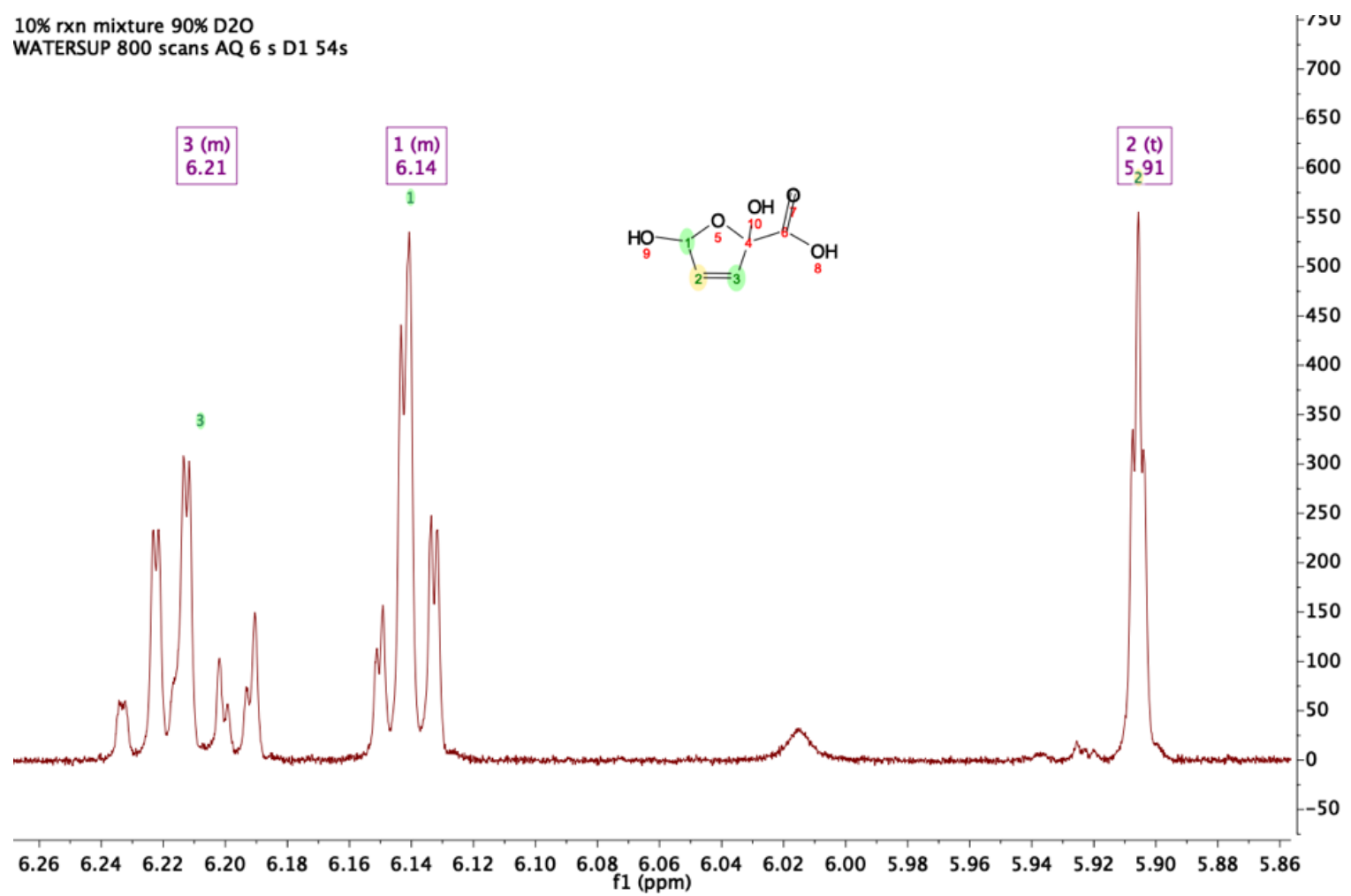

Figure S10: ${ }^{1} \mathrm{H}-\mathrm{NMR}$ spectrum assignments for 5-hydroxyfuroic acid in aqueous environment (see Scheme S1) 


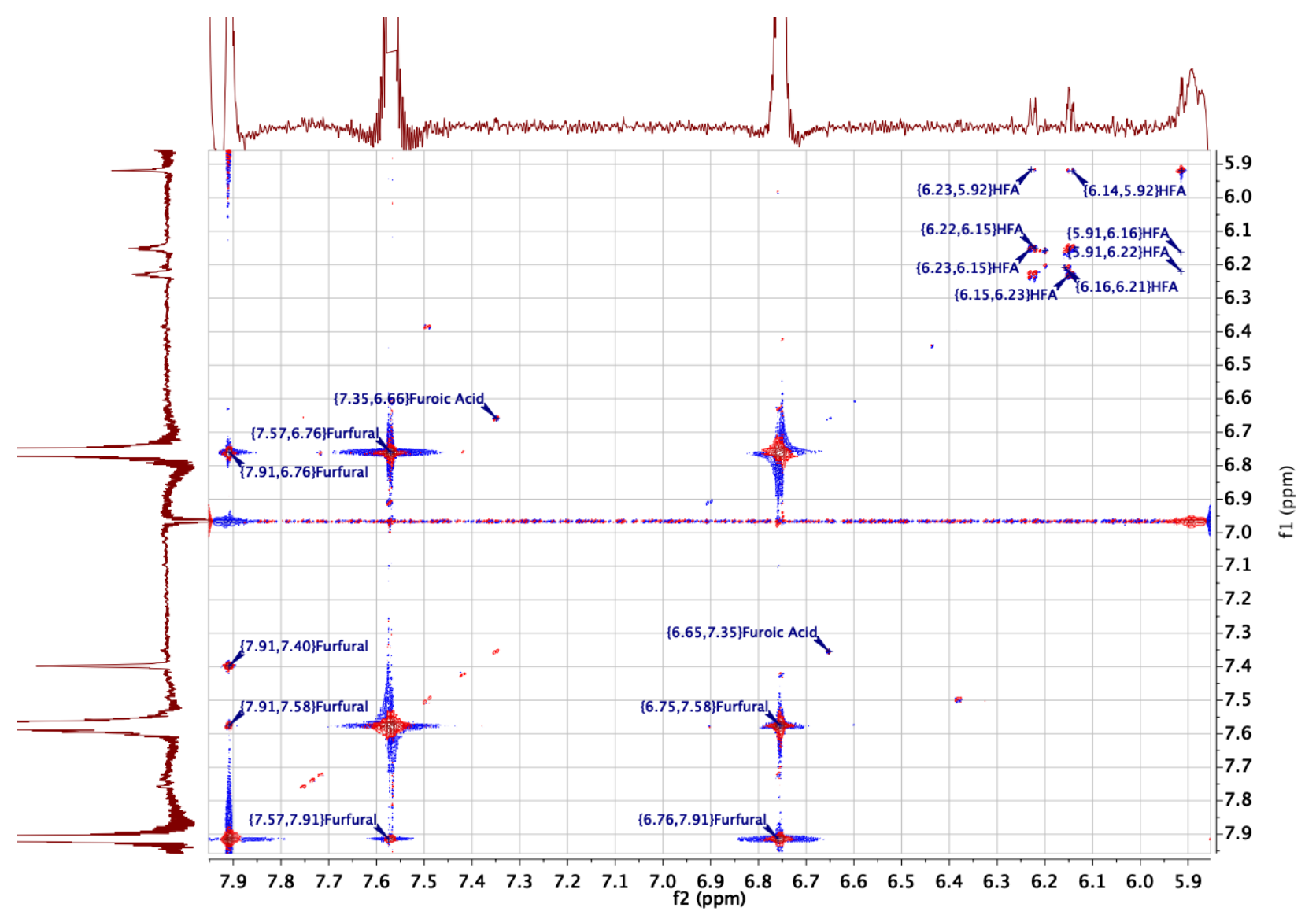

Figure S11: Full COSY spectra taken (range of 5.8 - 8.0 ppm due to interference of $\mathrm{H}_{2} \mathrm{O}$ )

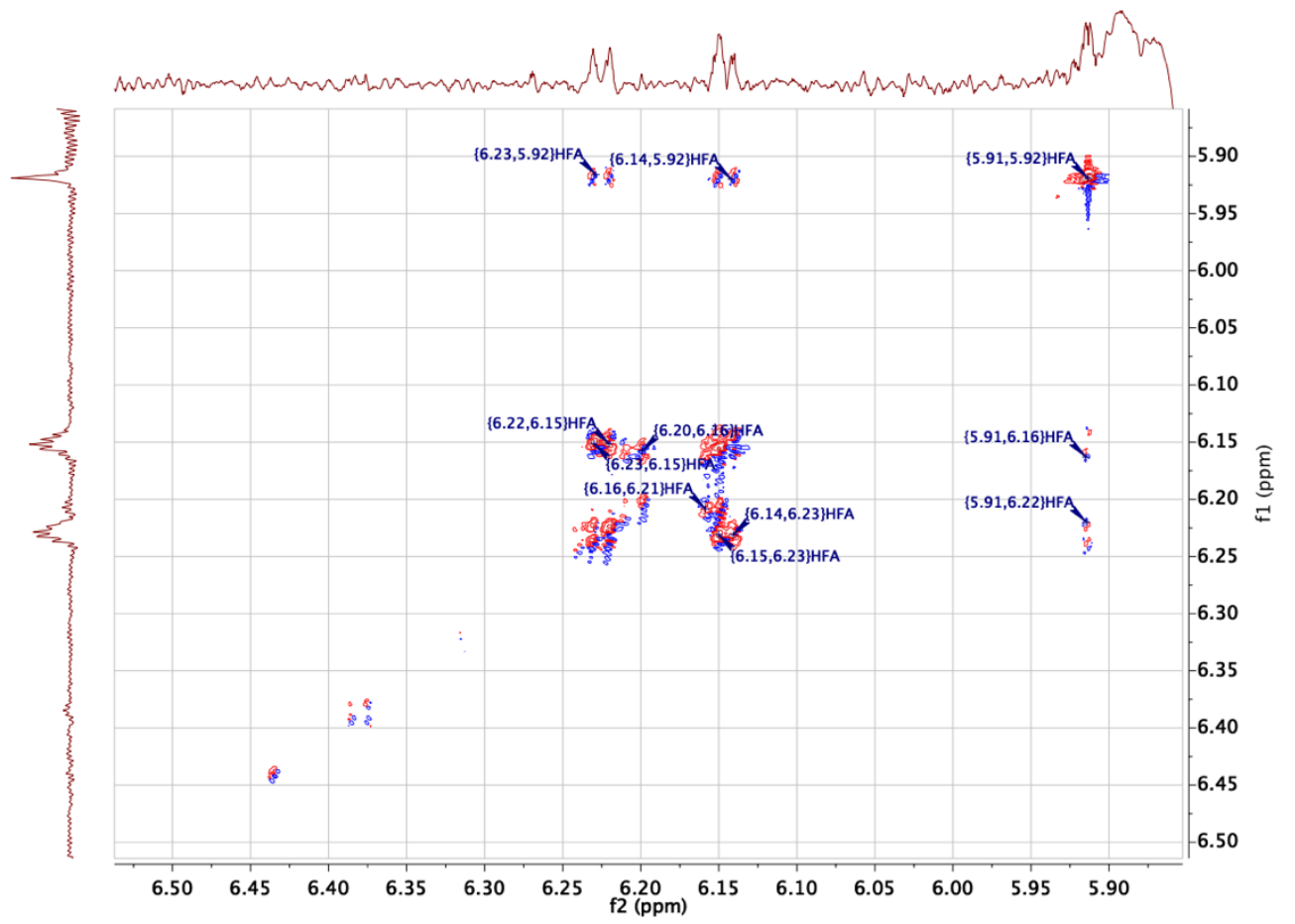

Figure S12: COSY spectra showing correlation between peaks at 6.22, 6.14, and $5.91 \mathrm{ppm}$. 


\section{SEM Image of Pt film used in ATR-SEIRAS}

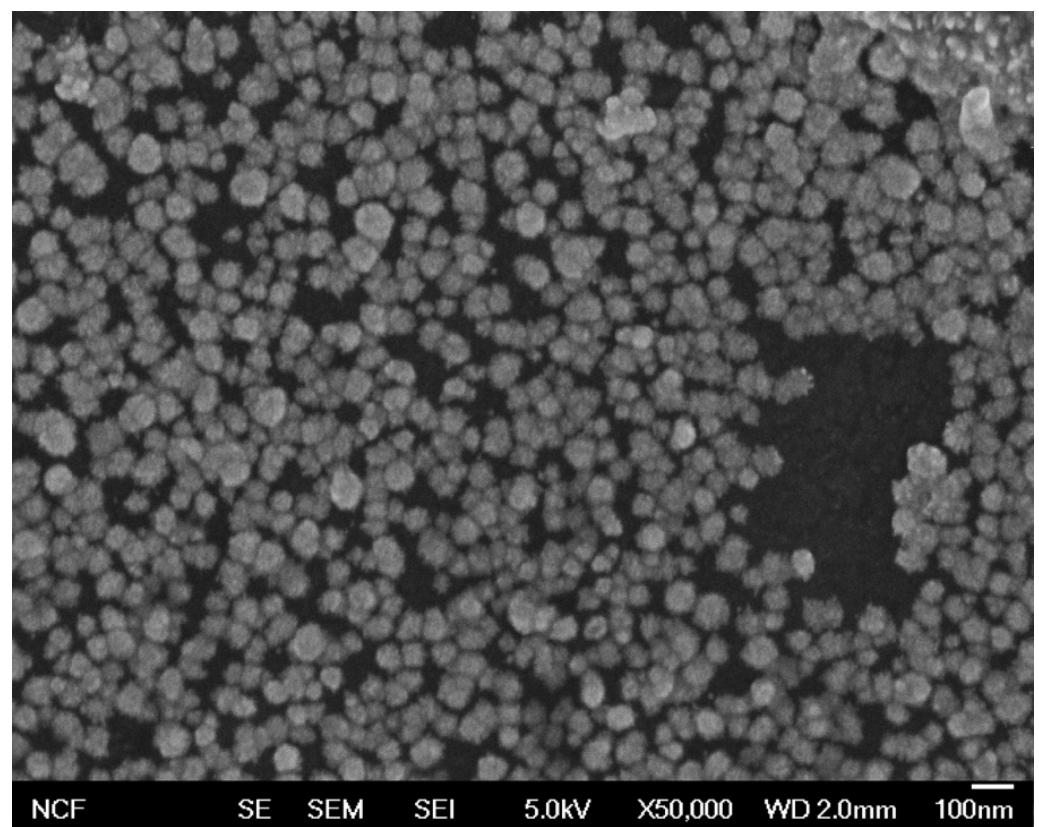

Figure S13: SEM Image of Pt film derived via the electroless deposition technique (details in text), showing characteristic nanoscale particle network. 


\section{ATR-IR Standards}

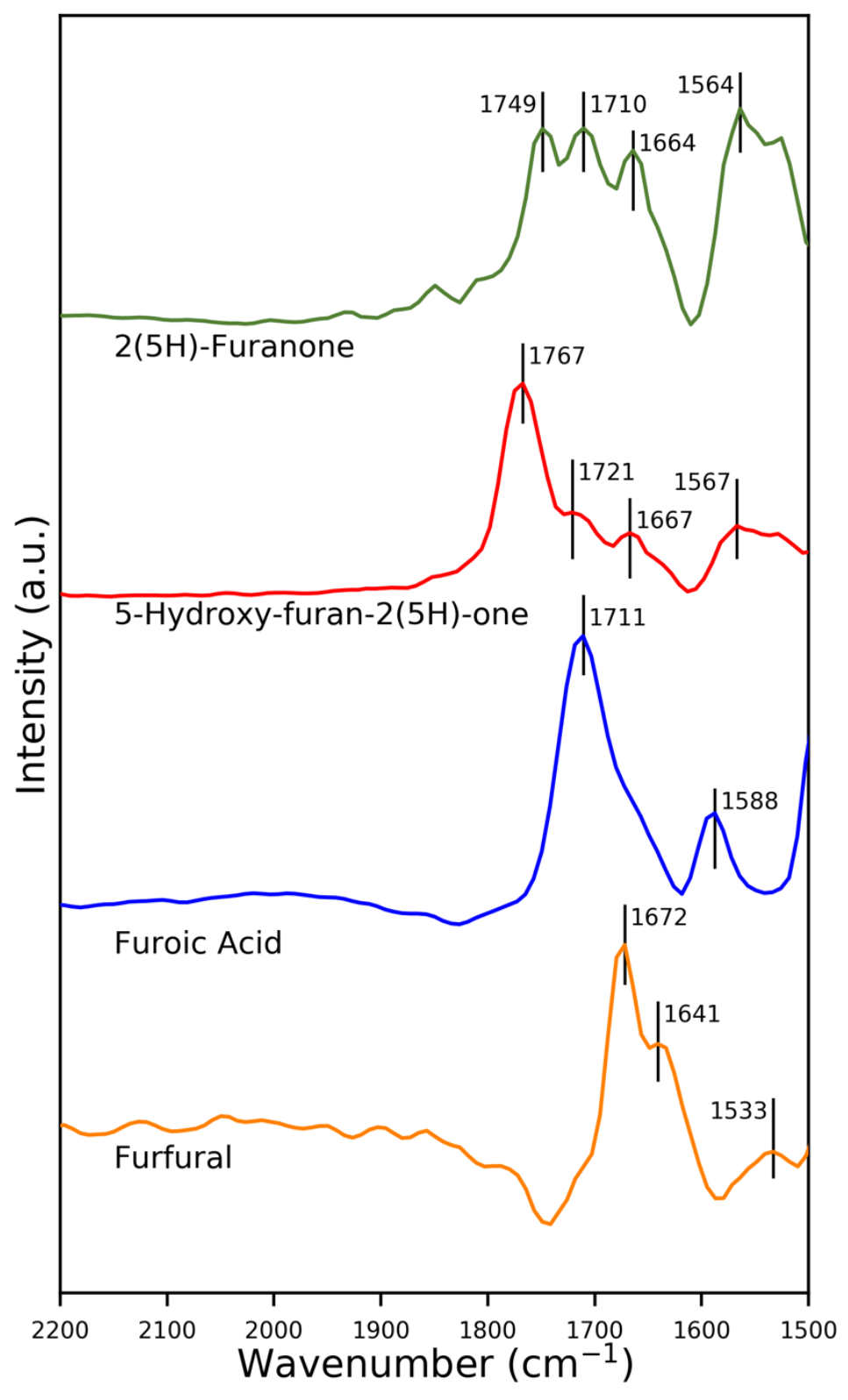

Figure S14: ATR-IR spectra of standards of 2(5H)-furanone (100 mM), 5-hydroxy-furan-2(5H)-one (10 $\mathrm{mM})$, furoic acid $(100 \mathrm{mM})$, and furfural $(100 \mathrm{mM})$ run on the bare Si crystal (no Pt film, no SEIRAS effect) in $0.25 \mathrm{M} \mathrm{HClO}_{4}$. Resolution $=16 \mathrm{~cm}^{-1}$. 


\section{Deconvolutions of furfural voltammetric stripping ion currents}
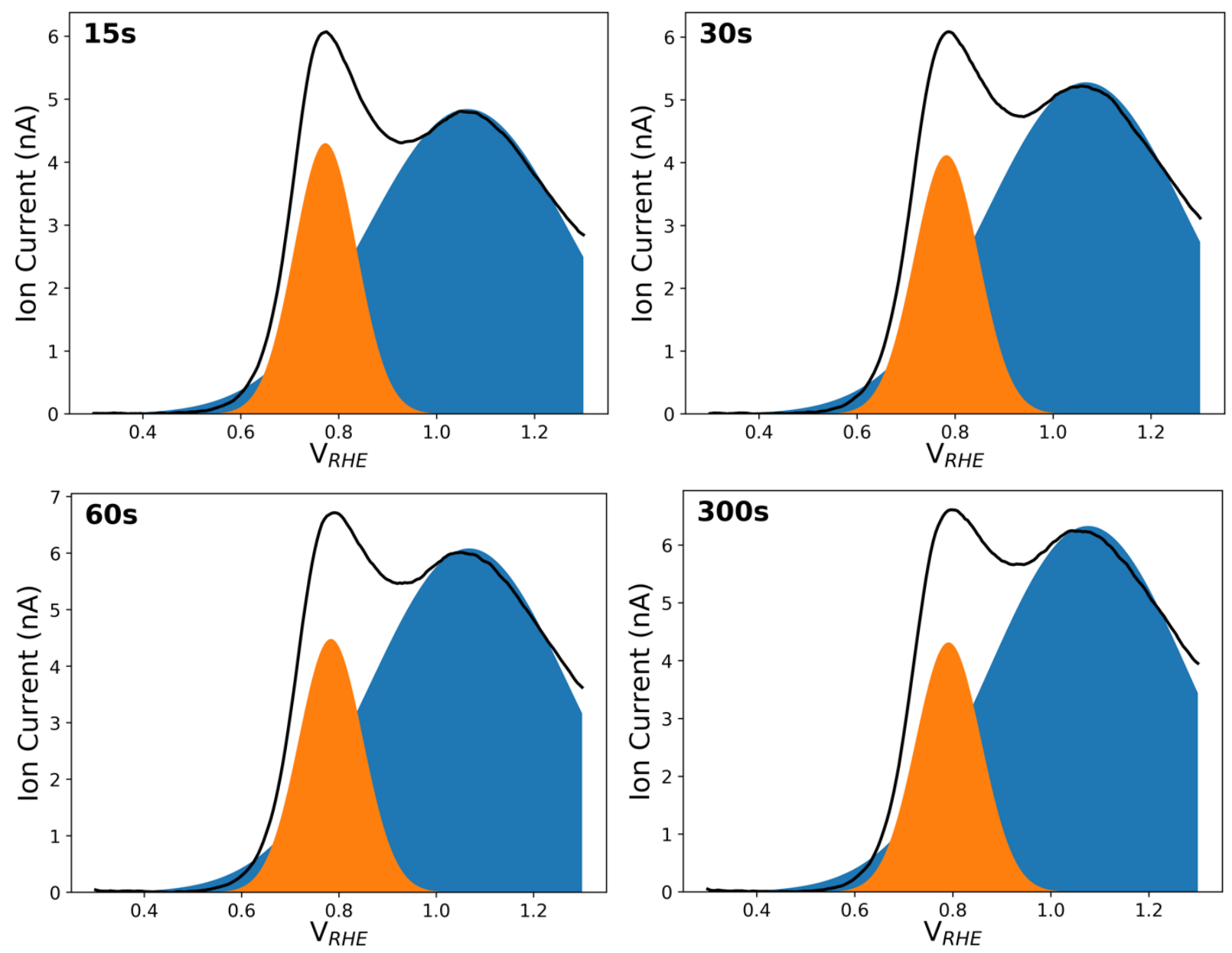

Figure S15: Deconvolution of peaks ("CO" component in orange, "furyl" component in blue) found in the $\mathrm{CO}_{2}$-OLEMS paired with voltammetric stripping at increasing adsorption times for furfural $(100 \mathrm{mM})$ on Pt Black in $0.25 \mathrm{M} \mathrm{HClO}_{4}$. Scan rate $=5 \mathrm{mV} / \mathrm{s}$ and flow rate $=1 \mathrm{~mL} / \mathrm{min}$. 


\section{Voltammetric stripping of furfural oxidation products at various adsorption times}

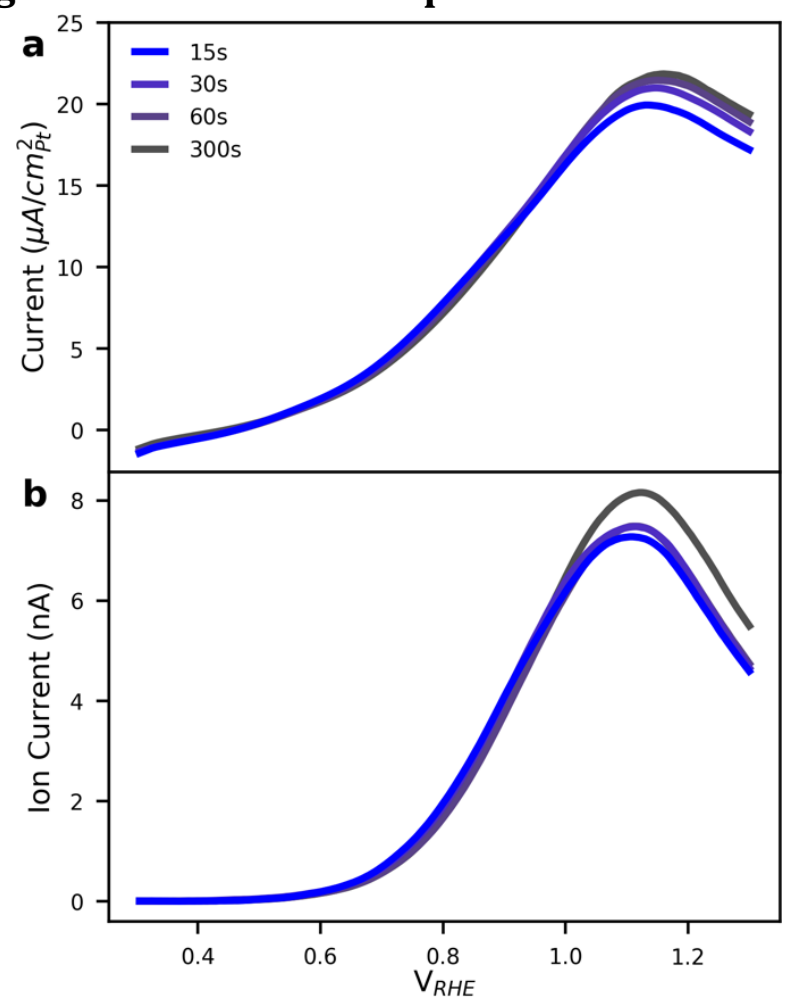

Figure S16: Voltammetric stripping (a) paired with $\mathrm{CO}_{2}$-OLEMS (b) at increasing adsorption times for furoic acid (100 mM) on Pt Black in $0.25 \mathrm{M} \mathrm{HClO}_{4}$. Scan rate $=5 \mathrm{mV} / \mathrm{s}$ and flow rate $=1 \mathrm{~mL} / \mathrm{min}$.

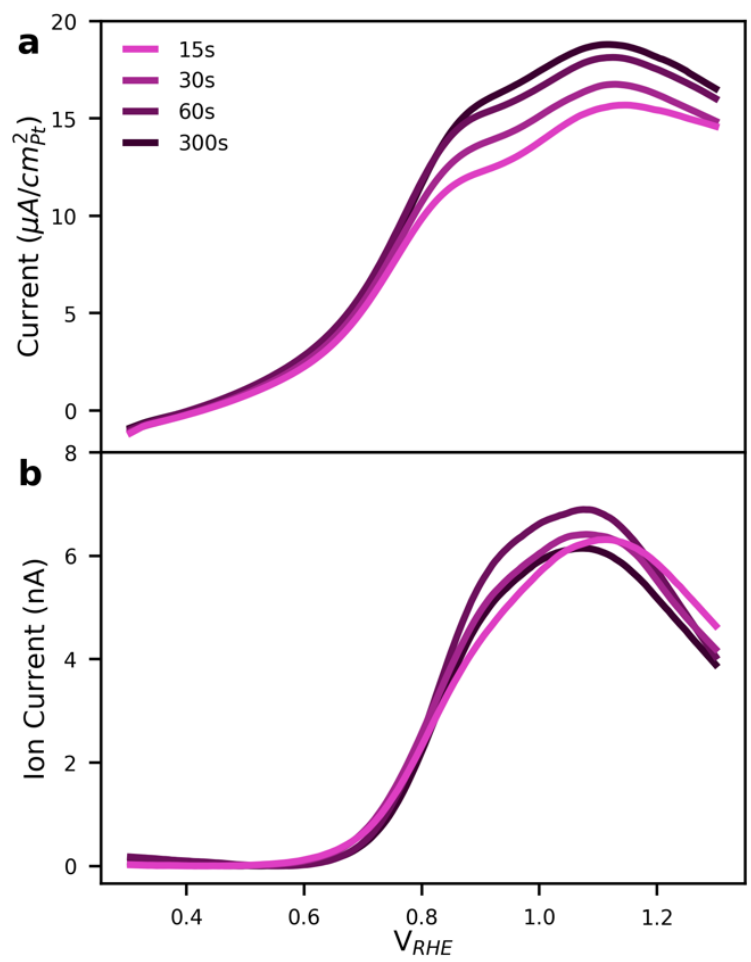

Figure S17: Voltammetric stripping (a) paired with $\mathrm{CO}_{2}$-OLEMS (b) at increasing adsorption times for furan $(\sim 50 \mathrm{mM})$ on Pt Black in $0.25 \mathrm{M} \mathrm{HClO}_{4}$. Scan rate $=5 \mathrm{mV} / \mathrm{s}$ and flow rate $=1 \mathrm{~mL} / \mathrm{min}$. 


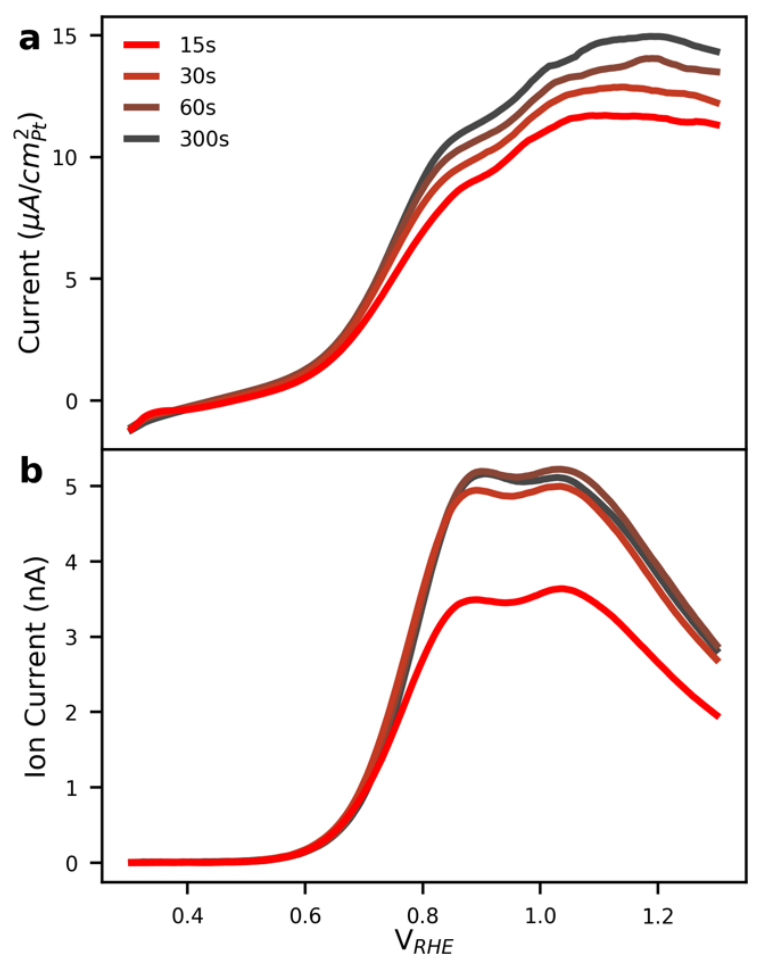

Figure S18: Voltammetric stripping (a) paired with $\mathrm{CO}_{2}-\mathrm{OLEMS}$ (b) at increasing adsorption times for 5-hydroxy-2(5H)-furanone (5 mM) on Pt Black in $0.25 \mathrm{M} \mathrm{HClO}_{4}$. Scan rate $=5 \mathrm{mV} / \mathrm{s}$ and flow rate $=1 \mathrm{~mL} / \mathrm{min}$.

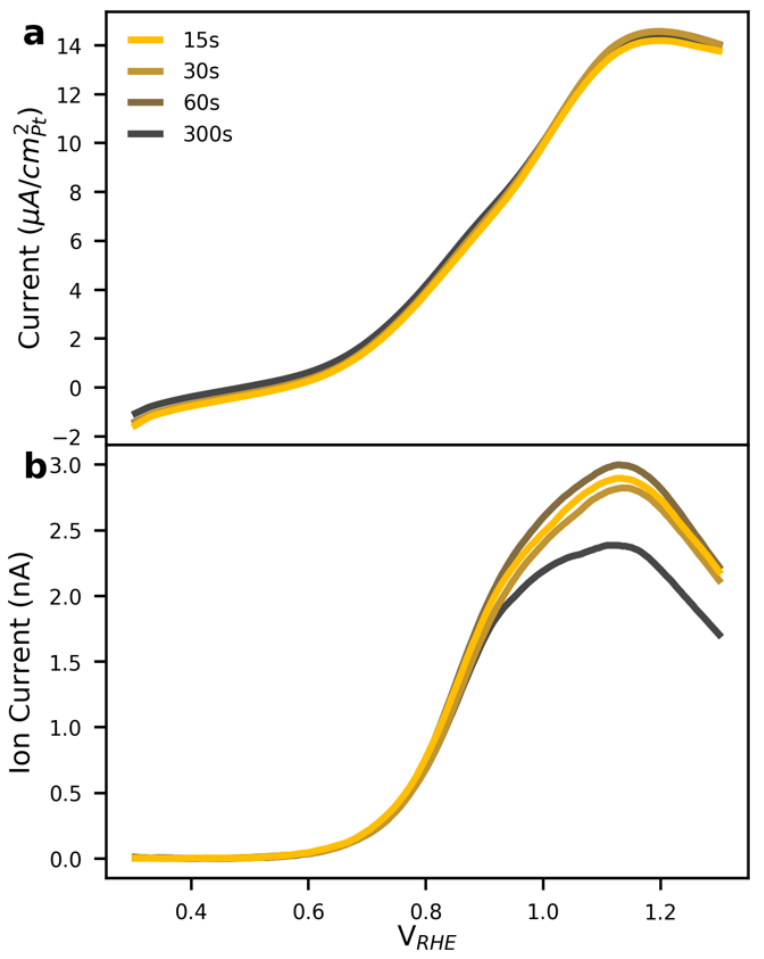

Figure S19: Voltammetric stripping (a) paired with $\mathrm{CO}_{2}$-OLEMS (b) at increasing adsorption times for maleic acid $(100 \mathrm{mM})$ on Pt Black in $0.25 \mathrm{M} \mathrm{HClO}_{4}$. Scan rate $=5 \mathrm{mV} / \mathrm{s}$ and flow rate $=1 \mathrm{~mL} / \mathrm{min}$. 